\title{
Job Satisfaction, Cost Management Knowledge, Budgetary Participation, and Their Impact on Performance
}

\author{
Aria Farahmita \\ Faculty of Economics and Business, Universitas Indonesia, \\ Jl. Prof. Dr. Sumitro Djojohadikusumo, Depok 16424, Jawa Barat, Indonesia
}

\section{ARTICLE INFO}

Keywords:

budget participation, cost management knowledge, job satisfaction, managerial performance
A B S T R A C T

This research aims to investigate the influence of the manager's level of cost management knowledge and job satisfaction on the relationship between budget participation and managerial performance. This research uses theoretical framework of individual performance who claims that individual performance is affected by three dimensions of performance which interact each other, i.e. dimensions of opportunity (participatory budget), dimensions of capacity (cost management knowledge) and the dimensions of willingness (job satisfaction). Hypotheses were tested using multivariate regression models that included interaction of three variables (3-way interaction) between budgetary participation, cost management knowledge and job satisfaction to test their effects on managerial performance. Research shows that budget participation which is given to managers with higher cost management knowledge and higher job satisfaction, had no impact to their managerial performance. Managerial performance variation can be explained by two dimensions. Based on our tests, the findings is consistent that budget participation has positive effect to managerial performance. Further test shows that managerial performance will increase when budget participation combined with high level of cost management knowledge or when budget participation combined with high job satisfaction ( 2 way interaction). The research also found that the combination of cost management knowledge with high job satisfaction without the opportunity to participate in the budgeting process will actually degrade the managerial performance.

\section{SARI PATI}

Riset ini bertujuan untuk meneliti pengaruh tingkat pengetahuan manajer tentang manajemen biaya dan kepuasan kerja terhadap hubungan antara partisipasi anggaran dan kinerja manajerial. Riset ini menggunakan kerangka teori tentang kinerja individu yang menyatakan bahwa kinerja individu dipengaruhi tiga dimensi yang 
saling berinteraksi, yaitu dimensi opportunity (partisipasi anggaran), dimensi capacity (pengetahuan manajemen biaya) dan dimensi willingness (kepuasan kerja). Hipotesis diuji menggunakan model regresi multivariate yang memasukkan interaksi tiga variabel (3 way interaction) antara partisipasi anggaran, pengetahuan manajemen biaya dan kepuasan kerja untuk diuji pengaruhnya terhadap kinerja manajerial. Hasil riset menunjukkan bahwa partisipasi anggaran yang diberikan kepada manajer dengan pengetahuan manajemen biaya dan kepuasan kerja yang tinggi tidak berdampak kepada peningkatan kinerja manajerial. Variasi kinerja manajerial dapat dijelaskan dengan dua dimensi. Dari semua pengujian, hasil menunjukkan bahwa partisipasi anggaran berpengaruh positif terhadap kinerja manajerial. Selanjutnya kinerja manajerial akan semakin meningkat ketika partisipasi anggaran dikombinasikan dengan pengetahuan tentang manajemen biaya yang semakin baik atau ketika partisipasi anggaran dikombinasikan dengan kepuasan kerja yang tinggi (2 way interaction). Riset ini juga menemukan bahwa kombinasi pengetahuan manajemen biaya yang semakin baik dengan kepuasan kerja yang tinggi tanpa disertai kesempatan berpartisipasi dalam proses penyusunan anggaran malah akan menurunkan kinerja manajerial.

\section{INTRODUCTION}

Participative budgeting is a term in accountancy which is defined as a process in which managers are involved and have the power to influence the budgeting (Shields and Shields, 1998). Participative budgeting has been one of many research topics in the field of management accounting for over 50 years. The first research to be published came from Argyris (1952) in Covaleski et al. (2003) which investigated the impact of participative budgeting to subordinate behavior. Argyris (1952) stated the need for subordinates to be given the opportunities to participate in the budgeting process. Simultaneously, this research topic extended to broader horizons with the vast number of empirical researches on the subject of participative budgeting which were motivated by theories in the field of economy, psychology, and sociology (Covaleski et al., 2003). The research on the direct impact of participative budgeting on performance has shown inconsistent results (Shields and Young, 1993; Agbejule and Saarikoski, 2006). This indicates that the influence of participative budgeting on performance are contextual. Some researches have also tried researching the contextual variables moderating the effects of participative budgeting on performance, for instance the environmental uncertainty (Govindarajan, 1986), product standardisation and process automation (Brownell and Merchant, 1990), organization size (Merchant, 1984), as well as organization hierarchy and control system (Jermias and Setiawan, 2008). In Indonesia, this includes motivational factors (Setiawaty, 2002), locus of control (Setyadi, 2002), as well as environmental uncertainty and job relevance (Meiliana, 2003).

Among many research found on participative budgeting, there is only a few which explore the variables related to the "individual" in the relationship between participative budgeting and managerial performance (Agbejule and Saarikoski, 2006). According to the research from Patterson et al. (1997), the factors which affect company performance the most are their employee's individual performances. Employee 
behavior and job satisfaction as well as the value a company places on their employee's well being will contribute to the increase of company performance. Those individual performances certainly may not succeed in achieving company objectives if they are not accompanied with the company's strategies. Here, the budgeting process becomes important as a medium for planning, coordinating, and controlling the efforts for achieving company objectives. Therefore, it is important to conduct a research which investigates the relationship between individual factor in relation to budgetary participation and individual performance in an organization.

The research about the influence of individual factor of managers on the relationship between participative budgeting and managerial performance has been conducted by Agbejule and Saarikoski (2006), examining the effects of moderation from cost management knowledge on the correlation between participative budgeting and managerial performance. The results have shown that participative budgeting will have a positive effect on managerial performance when the manager has higher knowledge of cost management. Another research about individual variables have also been conducted by Lopez et al. (2009) inSouth Korea, whichinvestigated the factors of job satisfaction and job relevant information as the intervening variables in the positive correlation between participative budgeting and managerial performance. In Indonesia, the individual variable that has been investigated is the motivation. In the research conducted by Setiawaty (2002), the influence of participative budgeting on managerial performance is examined using contingency approach, in which labor motivation is used as a moderating variable which strengthens the effect of participative budgeting towards managerial performance.

On the other hand, Blumberg and Pringle (1982) explained in their article about the performance theory, that there are three dimensions in interaction, which ultimately determines individual performance. Blumberg and Pringle (1982) criticizes that many researches on individual performance have failed to consider these dimensions which are capacity, willingness, and opportunity. By using the theoretical framework of Blumberg and Pringle (1982), the job satisfaction examined in the research of Lopez et, al (2009) becomes something that motivates employees to improve their performances, which is specifically categorized into the willingness dimension. Consequently, budgetary participation is categorized into the opportunity dimension. Using the theoretical framework of Blumberg and Pringle (1982), the job satisfaction variable is more suited to moderate the effects of budgetary participation on managerial performance. The research about participative budgeting (opportunity dimension) conducted by Setiawaty (2002) included the motivation variable into the willingness dimension in regards of the framework of Blumberg and Pringle (1982). The research of Agbejule and Saarikoski (2006) only utilized the capacity dimension (manager's level of cost management knowledge) and opportunity dimension (participative budgeting) for determining managerial performance.

This research aims to fill the research gap in Agbejule and Saariskoski (2006) by adding the third dimension of willingness. As highlighted by Blumberg and Pringle (1982), one of the willingness aspect that determines individual performance is job satisfaction. The capacity and the opportunities available alone are not sufficient to increase managerial performance, there needs to be a strong desire or motivation from managers in order to use capacity and opportunities for improving managerial performance. Job satisfaction can act as an indicator of desire and motivation for improving managerial performance.

\section{Research Objectives}

Based on the previously stated backgrounds, this research generally aims to investigate 
the influence of the manager's level of cost management knowledge and job satisfaction on the relationship between budget participation and managerial performance.The research question is whether participative budgeting combined with high level of cost management knowledge and job satisfaction will have a positive influence on managerial performance.

\section{Research Contributions}

This research is expected to make a contribution to the development of literature and practical world by: (1) serving as an addition to the literature of participative budgeting as a vital research area in management accounting. This research strives to investigate the relevant individual variables which, based on available information, has only been slightly examined. As previously stated, the most important factor which influences organizational performance is the performance of individuals within the organization. Middle-management's performance is an integral individual component in an organization. Middle-managers act as the middle line interconnecting the policies and strategies made by the top management and the low level management in the organization, (2) serving as an addition to the literature in researches on individual performance by providing empirical evidence for the theoretical framework proposed by Blumberg and Pringle (1982), that individual performance is affected by three dimensions in interaction which are capacity, willingness and opportunity. This research complements the previous research (Agbejule dan Saarikoski, 2006 dan Lopez et al. 2009) which has not investigated the interaction between the three variables present in the research on the influence of participative budgeting on individual performance, (3) investigating the variable of cost management knowledge which would hopefully benefit practitioners in acknowledging the importance of managerial knowledge about using budgetary information for performance evaluation and (4) investigating the variables on job satisfaction which would boost individual performance so that companies may foster the role of its human resource development in order to increase the company's organizational performance.

\section{Participative budgeting and performance}

The role of participative budgeting in strengthening managerial performance has been discussed extensively in a number of accountancy literature. There is a belief that participative budgeting will benefit the organization by facilitating better communications, giving motivation and enhancing commitment, thus improving the performance. Nevertheless, research results show inconsistency. Shields and Young (1993) who did a review about the influence of participative budgeting towards performance, found that there were 24 hypothesis tests which showed significant effects and 35 hypotheses showing insignificant effects or unprecedented results.

The research in which positive influence from participative budgeting on performance were found include one from Brownell and Dunk (1991), Kren (1990) and Dunk (1993). Other studies found that participative budgeting had negative impact on performance. The variable on performance which was investigated through different measurement methods, such as role ambiguity (Chenhall and Brownell, 1988), job related tension (Kenis, 1979) and managerial performance (Mia, 1988). Mia's research (1988) did a survey on middlelevel managers from companies in Australia. The results have shown that participative budgeting had negative impact towards managers whose behaviors were indecent and had low motivation. On the contrary, the research have also shown that participative budgeting had positive influence on the performance of managers who had decent behavior and high motivation. Based on that research, it can be concluded that research on the relationship between participative budgeting and performance should use a contingency approach. Researchers need to consider the moderating variables when investigating the influence of budgetary participation on performance, because 
the influence may differ depending on the situation.

\section{Performance Theory}

This research utilizes the theoretical framework of Blumberg and Pringle (1982) in order to explain the influenc of participative budgeting on managerial performance. Blumberg and Pringle (1982) criticized research investigating individual performance for having only associated performance with one or two variables. Previous researches were deemed as failed attempts for showing strong and consistent predictions on performance. According to Blumberg and Pringle (1982), individual performance is affected by three dimensions which are capacity, willingness, and opportunity. The theoretical framework proposed by Blumber and Pringle (1982) is as follows:

\section{Performance $=\mathrm{f}$ (capacity $\mathrm{X}$ willingness X opportunity)}

If one of the dimensions come at a lower level, it would result in decrease in performance. Capacity is the cognitive and psychological capability that enables individuals to work effectively. This dimension reflects the effects of individual knowledge, skill, intelligence, age, helath condition, level of education, stamina endurance, motoric skills and similar aspects.

The willingness dimension refers to the psychological and emotional characteristics which affect the degree to which an individual may do his/ her job. Willingness reflects the behavioral effects from motivation, job satisfaction, personality, attitude, norms, values, job status, job characteristics, role perception, self image, and other traits.

The third dimension is opportunity. Opportunity interacts with capacity and willingness in order to boost performance, still, as are with willingness and capacity, opportunity alone is not capable of boosting performance. Although the individual may possess the willingness and capacity for taking part in the behavior that is expected to heighten performance, this still cannot be achieved if the indvidual does not have the opportunity to do it. Opportunity refers to the technical system component, such as equipments, supplies, materials, leadership behavior, organizational policy, as well as rules and procedures. Participative budgeting shows the opportunity dimension which gives individual managers the chance to participate in constructing the budget plan in the hopes of improving managerial performance.

\section{Prior Research}

Dearman and Shields (2001) show the important role of knowledge as a vital component in determining performance. Shields and Young (1994) has stated that cost management knowledge may help managers understand business processes and organization activities comprehensively. By understanding how an activity may be achieved and the reason for incurring costs, managers will be able to enhance repairs on processes which are cost-beneficial. This component is crucial in fulfilling the budget.

Research by Agbejule and Saarikoski (2006) investigated the moderating effects of cost management knowledge as a "capacity" dimension in affecting the relationship between participative budgeting and managerial performance. The results have shown that the impact of participative budgeting on managerial performance will remain positive as managers' cost management knowledge increases. Agbejule and Saarikoski (2006) only focused on individual characteristics, knowledge (capacity dimension) and "opportunity". The research never considered the "willingness" dimension. Referring to the theoretical framework of Blumberg and Pringle (1972), job satisfaction is a "willingness" dimension which has an impact on individual performance. Most of the researches on participative budgeting place job satisfaction as a dependent variable, as stated in Brownell (1982, 1983), Chenhall (1986), and Dunk (1992) in Shields and Shields (1998). 
The research of Lopez et al. (2009) conducted an examination on middle-level managers in South Korea and found that there was indirect influence of budgetary participation upon performance through the job satisfaction factor. This research made use of the "path model" analysis in finding the relationship.

The interaction between three variables around inividual performance can be explained using the theoretical model of Blumberg and Pringle (1982) as previously mentioned. In management accounting researches about budgeting, participative budgeting is defined as an opportunity dimension, cost management knowledge defined as the capacity dimension, and job satisfaction is defined as the willingness dimension. These three dimensions interact with each other in explaining the variations of managerial performance.This is consistent with the notion from Shields and Shields (1998) who conducted a review about participative budgeting by categorizing it into the theories of economy, psychology, and sociology. The interaction between the three variables in the participative budgeting research which inclines to the theoretical framework of Blumberg and Pringle (1982) can be explained using the psychology theory. Shields and Shields (1998) has identified that there are three mechanisms in participative budgeting, which are value, cognitive, and motivational goals. Theoretically, the value goal can affect an individual's mental and satisfaction because participatory process (as an "opportunity" dimension) may cause middlemanagers to experience "self respect" and feelings of equality which emerged from the opportunity to express his/her values. Motivational mechanisms (as a "willingness" dimension) refers to the impact resulting from increasing trust and sense of control which would induce stronger commitment, receptive behavior towards budgetary decisions, leading to enhanced performance.

\section{Hypothesis Development}

In accordance with the theoretical framework of
Blumberg and Pringle (1982) as well as Shields and Shields (1998), participative budgeting would yield the highest benefit in strengthening managerial performance when combined with high level of cost management knowledge and job satisfaction. In other words, cost management knowledge and job satisfaction would strengthen the impact of budgetary participation on managerial performance. Hence, it can be predicted that budgetary participation ("opportunity" dimension), cost management knowledge ("capacity" dimension) and job satisfaction ("willingness" dimension) would interact each other in affecting managerial performance. Budgetary participation accompanied with high level of cost management knowledge and job satisfaction will produce higher impact on managerial performance compared to other conditions.

The opportunity to participate in the budgeting process would not yield benefit in enhancing managerial performance if the managers have low level of cost management knowledge and job satisfaction. This would result in decreased quality of decision making and job completion which may lead to diminished managerial performance. Hence, the first hypothesis to be proposed in this research is:

H1: Budgetary participation combined with higher cost management knowledge and job satisfaction would produce higher managerial performance (three-way interaction).

The second hypothesis aims to confirm the research results of Agbejule and Saarikoski (2006) which focused on two dimensions of performance, namely "opportunity" and "capacity". In this research, the implications can bee seen after considering the existence of another dimension which is job satisfaction (willingness). Higher cost management knowledge would strengthen the positive effect of budgetary participation on managerial performance. The hypothesis is as follows: 
H2: The higher the cost management knowledge, the stronger the positive effect of budgetary participation on managerial performance becomes.

The next hypothesis is based on the results of Setiawaty (2002) who also focused on two performance dimensions which were "opportunity" and "willingness" by using labor motivation as a factor that could enhance the effects of participative budgeting on managerial performance. Motivation is a "willingness" dimension which, in this research, is represented by the factor on job satisfaction. It is predicted that if access to participate in the budgeting process is given to managers with high job satisfaction, then the effects of budgetary participation on managerial performance would increase.

H3: The higher the level of job satisfaction, the stronger the positive effect of participative budgetin on managerial performance.

\section{METHODS}

\section{Data and Sampel}

Data is collected through questionnaires which were put together based on previous researches. The samples or respondents are selected through convenience and purposive sampling, with the criteria as follows:

- Middle-level managers, individuals whose positions are among that of supervisor, assistant manager, junior manager, manager, or senior manager.

- Employed in an organization that utilizes budgeting mechanism as planning and controlling tools.

- Have at least one year's tenure of office, to ensure that the individuals already have a good understanding about budgeting mechanism in the workplace and can evaluate their own performance.

- In order to grasp the concept or various levels of budgetary participation for each individual within the organization, respondents are not required to come from an accounting, finance, or budgeting division

\section{Variable Measurements}

The questionnaire used to measure the variables of this research.

\section{- Managerial Performance}

Measured using the questions from Mahoney et al. (1965) which have been much used for researches on participative budgeting and performance, as has been used by Agbejule and Saarikoski (2006) and Jermias \& Setiawan (2008). Managerial performance is measured using each individual manager's personal perception of himself/herself (self rating performance). The components measured include planning, investigating, coordinating, evaluating, supervising, staffing, negotiating, and representing. The measurement scale used conforms to that of Mahoney et al. (1965) of which value $=1$ (significant below average) to 7 (significant above average). Managerial performance of every respondent will be measured using the average score of all questions.

- Participative budgeting

Measured using 6 questions as were used in the research by Agbejule and Saarikoski (2006). The scale used is the likert scale with 1 being the lowest value of participation to 7 being the highest value of participation. The level of participative budgeting of each respondent will be gathered from the average score of all questions.

- Cost Management Knowledge

Referring to Shields and Young (1994) as used in Agbejule and Saarikoski (2006) which consisted of 7 questions. The questions revolve around the knowledge of cost management in general, not about the budgeting proccess. It is expected that with good cost management knowledge, managers would have a good capability of determining how 
and what amount would be most appropriate when planning the budget. The scale used is the likert scale, from the value of 1 (strongly disagree) to 7 (strongly agree). The level of cost management knowledge of each respondent will be gathered from the average score of all questions.

- Job Satisfaction

Measured using the Minnesota Satisfaction Questionnaire (Weiss et al., 1967) consisting of 20 questions regarding individual perfomance. The masurement uses the scale of 1 (very dissatisfied) to 5 (very satisfied). In data processing, these scores will be adjusted to the scale of 1 to 7 for simpler understanding and interpretation. Each respondents' level of job satisfaction will be gathered from the average score of all questions.

\section{Hypothesis Testing}

Hypothesis testing uses the multivariable regression model as follows:

$$
\begin{aligned}
& \text { Perf }=\alpha_{0}+\alpha_{1} B P_{i}+\alpha_{2} C M_{i}+\alpha_{3} S a t_{i} \\
& +\alpha_{4} C M_{i} * B P_{i}+\alpha_{5} \text { Sat }_{i} * B P_{i}+\alpha_{6} C M_{i} * \text { Sat }_{i} \\
& +\alpha_{7} C M_{i} * \mathrm{Sat}_{i}^{*} B P_{i}+e_{i}
\end{aligned}
$$

Whereas: Perf $=$ Managerial performance; BP = Budgetary Participation; $\mathrm{CM}=$ Cost Management Knowledge; $\mathrm{CM}^{*} \mathrm{BP}=$ Interaction between budgetary participation and cost management knowledge; Sat*BP = Interaction between budgetary participation and job satisfaction; $\mathrm{CM} *$ Sat $=$ Interaction between cost management knowledge and job satifaction; $\mathrm{CM}^{*} \mathrm{Sat} * \mathrm{BP}=$ Interaction between cost management knowledge, job satisfaction and budgetary participation (3 way interaction); $\mathrm{e}=$ error.

Hypothesis 1 will be supported if coefficient $\alpha_{7}>0$ Hypothesis 2 will be supported if coefficient $\alpha_{4}>0$, and hypothesis 3 will be supported if coefficient $\alpha_{5}>0$.
The use of interaction variable in the test model would be vulnerable to multicolinearity in the regression. In order to resolve this problem, following what was done by Jermias and Setiawan (2008), then "centering" is performed on independent variables. The value of centering is the original value deducted by average value.

\section{RESULTS AND DISCUSSIONS}

The results of questionnaire distribution produced 116 respondent data which can act as samples to be processed. The questionnaires are distributed during October - November 2012 in Jakarta and Depok directly to respondents and through emails. The following are details of questionnaire data collected:

Table 1. Questionnaire Distribution Results

\begin{tabular}{lc}
\hline Items & $\begin{array}{c}\text { Number of } \\
\text { Samples }\end{array}$ \\
\hline Distributed questionnaires & 150 \\
Questionnaires retrieved & 125 \\
-/- Incomplete questionnaires & $(9)$ \\
\hline $\begin{array}{l}\text { Number of questionnaires } \\
\text { to process }\end{array}$ & 116 \\
\hline Response rate & $77.33 \%$ \\
\hline
\end{tabular}

The response rate is considerably high, approximately $77 \%$ because most of the questionnaires were directly distributed to the respondents in order to ensure the completion and the return of questionnaire sheets.

Respondent profile is as follows:

Table 2. Respondent Profile

\begin{tabular}{lc}
\hline Items & $\begin{array}{c}\text { Number of } \\
\text { Samples }\end{array}$ \\
\hline Age & 34 Years \\
\hline Tenure & 6.9 Years \\
\hline Educational Backgrounds & \\
- Economy/Business & $62 \%$ \\
- Non-Economy/Business & $38 \%$ \\
\hline
\end{tabular}


In table 2 , it is shown that the average age of respondents points to a reasonable age for middle-level managers which is 34 years old. The average tenure of office is currently 6,9 years which is a sufficient period in order for respondents to have knowledge of or to have been involvd in the budgeting process at his/her current office. Furthermore, $62 \%$ of the respondents come from economy/business educational backgrounds while $38 \%$ of them come from noneconomy/business backgrounds. This shows an appropriate composition for gathering various cost management knowledge from each individual involved in the budgeting process.

\section{Descriptive Statistics and Correlations}

Descriptive statistics are shown in Table 3. The score for the variable on job satisfaction is the value which has been adjusted to the scale of $1-7$. The mean values of all variables exceed 4 , which would be in the middle of the likert scale (1-7). This means that the mean value of performance tends to be higher than average, the mean value of budgetary participation is considerably high, cost management knowledge is considerably high as well, and the average score of job satisfaction falls into level "satisfied".
The results of the reliability test shows that all reliable variables have cronbach alpha value of more than 0,6, which means that respondent's answers are consistent and stable enough as a suitable form of measurement for research variables. The validity test shows that all questions have significant correlation with each variable's measured average score (managerial performance, budgetary participation, and job satisfaction). This means that all variables are valid, all questions regarding each variable in the questionnaire can reveal the dimension to be measured.

The correlation between variables is as shown in Table 4.

Correlation testing shows that the variables on budgetary participation (BP), cost management knowledge (CM), job satisfaction (Sat) each has positive, significant correlation with managerial performance (Perf). This means that as budgetary participation increases, so would the cost management knowledge and job satisfaction in relation to improved managerial performance. Before taking into consideration the other affecting variables, the interaction variables between

Table 3. Descriptive Statistics, Reliability and Validity Tests

\begin{tabular}{lcccc}
\hline & $\begin{array}{c}\text { Perf } \\
\text { (Managerial } \\
\text { Performance) }\end{array}$ & $\begin{array}{c}\text { BP } \\
\text { (Budgetary } \\
\text { Participation) }\end{array}$ & $\begin{array}{c}\text { CM } \\
\text { (Cost } \\
\text { Management } \\
\text { Knowledge) }\end{array}$ & $\begin{array}{c}\text { Sat } \\
\text { (Job } \\
\text { Satisfaction) }\end{array}$ \\
\hline Mean & 4.95 & 4.49 & 4.46 & 5.21 \\
\hline Median & 5.00 & 4.50 & 4.60 & 5.30 \\
\hline Maximum & 7.00 & 7.00 & 7.00 & 7.00 \\
\hline Minimum & 2.60 & 1.00 & 1.00 & 2.80 \\
\hline Std. Dev. & 0.97 & 1.39 & 1.29 & 0.66 \\
\hline Reliability Test & & & & \\
(Cronbach Alpha) & 0,868 & 0,931 & 0,884 & 0,891 \\
\hline & (Reliable) & (Reliable) & (Reliable) & (Reliable) \\
\hline Validity Test & Valid & Valid & Valid & Valid \\
\hline & & & & 116 \\
\hline Observations & 116 & 116 & 116 & \\
\hline
\end{tabular}


Table 4. Pearson Correlation

\begin{tabular}{|c|c|c|c|c|c|c|c|c|}
\hline Variable & Perf & BP & $\mathrm{CM}$ & Sat & $\mathrm{CM}^{*} \mathrm{BP}$ & Sat*BP & $\mathrm{CM} *$ Sat & CM*Sat*BP \\
\hline \multirow{2}{*}{ Perf } & 1.000 & & & & & & & \\
\hline & ---- & & & & & & & \\
\hline \multirow{2}{*}{ BP } & 0.465 & 1.000 & & & & & & \\
\hline & $0.000^{* * *}$ & ---- & & & & & & \\
\hline \multirow{2}{*}{$\mathrm{CM}$} & 0.472 & 0.563 & 1.000 & & & & & \\
\hline & $0.000^{* * *}$ & $0.000 * * *$ & ----- & & & & & \\
\hline \multirow{2}{*}{ Sat } & 0.375 & 0.189 & 0.085 & 1.000 & & & & \\
\hline & $0.000^{* * *}$ & $0.0412^{* *}$ & 0.364 & ---- & & & & \\
\hline \multirow{2}{*}{$\mathrm{CM} * \mathrm{BP}$} & -0.069 & -0.314 & -0.406 & 0.028 & 1.000 & & & \\
\hline & 0.458 & $0.000 * * *$ & $0.000 * * *$ & 0.761 & ---- & & & \\
\hline \multirow{2}{*}{ Sat*BP } & 0.103 & 0.084 & 0.029 & -0.179 & -0.013 & 1.000 & & \\
\hline & 0.269 & 0.364 & 0.753 & $0.053^{*}$ & 0.888 & ---- & & \\
\hline \multirow{2}{*}{$\mathrm{CM}^{*}$ Sat } & -0.079 & 0.031 & 0.105 & -0.191 & 0.021 & 0.522 & 1.000 & \\
\hline & 0.398 & 0.734 & 0.261 & $0.039^{* * *}$ & 0.821 & $0.000 * * *$ & ---- & \\
\hline \multirow{2}{*}{ CM*Sat*BP } & 0.194 & 0.056 & 0.047 & 0.424 & 0.145 & -0.479 & -0.692 & 1.000 \\
\hline & $0.036^{* *}$ & 0.550 & 0.611 & $0.000 * * *$ & 0.118 & $0.000^{* * *}$ & $0.000 * * *$ & ---- \\
\hline \multicolumn{9}{|c|}{ Pearson's correlation; probabilita t-stat is in italic } \\
\hline \multicolumn{9}{|c|}{$\begin{array}{l}* * * \text { significant at } 1 \% \\
* * \text { significantat } 5 \%\end{array}$} \\
\hline
\end{tabular}

cost management knowledge, job satisfaction and budgetary participation (CM*Sat*BP) have positive, significant correlation on managerial performance.

The hypothesis testing model which contained several interaction variables is very vulnerable to multicollinearity problem. Hence, in order to resolve the multicollinearity problem in this research, the variable used will be the value after "centering" has been performed, which is the value of each variable deducted by average score. This procedure was also conducted by Jermias and Setiawan (2008) in using the model which involved 3 interaction variables. After "centering" is done, then there would be no multicollinearity problem, since the value of VIF will be less than 10 (Gujarati, 2003), result is not displayed .

\section{Hypothesis testing and Analysis}

The results from regression done for hypothesis testing are listed in the Table 5 (already adjusted from eviews regression output for one way testing).

Column 1 in the table shows regression results for the model without calculating the interaction variables. Column 2 shows regression results affected by the interaction variable on $\mathrm{CM}^{*} \mathrm{BP}$ as was the case in the preceding research by Agbejule and Saarikoski (2006). Column 3 shows regression results affected by the interaction variable on Sat*BP as done in the previous research by Setiawaty (2002). Column 4 shows regression results by inputting all 2-way-interaction variables which are $\mathrm{CM}^{*} \mathrm{BP}$, Sat*BP and $\mathrm{CM}^{*}$ Sat. Column 5 shows the hypothesis testing model which has calculated all variables, including the 3-wayinteraction variables on $\mathrm{CM}^{*} \mathrm{Sat} * \mathrm{BP}$. 
Table 5. Hypothesis Testing

\begin{tabular}{|c|c|c|c|c|c|c|}
\hline Variable & $\begin{array}{l}\text { Expected } \\
\text { Coefficient }\end{array}$ & (1 way) & $\left(\mathrm{CM}{ }^{*} \mathrm{BP}\right)$ & (Sat*BP) & (2 way) & (3 way) \\
\hline & & 1 & 2 & 3 & 4 & 5 \\
\hline \multicolumn{7}{|c|}{$\begin{array}{l}\text { Dependent Variable: Perf } \\
\text { Observation: } 116\end{array}$} \\
\hline $\mathrm{C}$ & & $\begin{array}{r}0.848 \\
(0.083) \\
\end{array}$ & $\begin{array}{r}4.873 \\
(0.000) \\
\end{array}$ & $\begin{array}{r}4.934 \\
(0.000) \\
\end{array}$ & $\begin{array}{r}4.859 \\
(0.000) \\
\end{array}$ & $\begin{array}{r}4.859 \\
(0.000) \\
\end{array}$ \\
\hline $\mathrm{BP}$ & + & $\begin{array}{r}0.160 \\
(0.007)^{* *}\end{array}$ & $\begin{array}{r}0.220 \\
(0.001)^{* * * *} \\
\end{array}$ & $\begin{array}{r}0.275 \\
(0.000)^{* * * *} \\
\end{array}$ & $\begin{array}{r}0.153 \\
(0.008)^{* *}\end{array}$ & $\begin{array}{r}0.153 \\
(0.008)^{* *} \\
\end{array}$ \\
\hline $\mathrm{CM}$ & + & $\begin{array}{r}0.239 \\
(0.000)^{* * *}\end{array}$ & $\begin{array}{r}0.277 \\
(0.000)^{* * *} \\
\end{array}$ & & $\begin{array}{r}0.303 \\
(0.000)^{* * *} \\
\end{array}$ & $\begin{array}{r}0.307 \\
(0.000) * * *\end{array}$ \\
\hline Sat & + & $\begin{array}{r}0.445 \\
(0.000)^{* * *}\end{array}$ & & $\begin{array}{r}0.473 \\
(0.000)^{* * * *} \\
\end{array}$ & $\begin{array}{r}0.436 \\
(0.000) * * * \\
\end{array}$ & $\begin{array}{r}0.449 \\
(0.000)^{* * *}\end{array}$ \\
\hline $\mathrm{CM} * \mathrm{BP}$ & $\mathrm{H} 2:+$ & & $\begin{array}{r}0.008 \\
(0.021)^{* *}\end{array}$ & & $\begin{array}{r}0.073 \\
(0.023)^{* *}\end{array}$ & $\begin{array}{r}0.076 \\
(0.024) * * \\
\end{array}$ \\
\hline Sat*BP & $\mathrm{H} 3:+$ & & & $\begin{array}{r}0.115 \\
(0.055)^{*} \\
\end{array}$ & $\begin{array}{r}0.208 \\
(0.004) * * * \\
\end{array}$ & $\begin{array}{r}0.204 \\
(0.005)^{* *} \\
\end{array}$ \\
\hline $\mathrm{CM}^{*}$ Sat & $?$ & & & & $\begin{array}{r}-0.204 \\
(0.026)^{* *}\end{array}$ & $\begin{array}{r}-0.224 \\
(0.060) * \\
\end{array}$ \\
\hline $\mathrm{CM}^{*} \mathrm{Sat}^{*} \mathrm{BP}$ & $\mathrm{H} 1:+$ & & & & & $\begin{array}{r}-0.016 \\
(0.345) \\
\end{array}$ \\
\hline \multicolumn{2}{|l|}{ Adj $R^{2}$} & 0.354 & 0.289 & 0.299 & 0.401 & 0.396 \\
\hline \multicolumn{2}{|l|}{ F-stat } & 21.994 & 16.574 & 17.389 & 13.831 & 11.764 \\
\hline \multicolumn{2}{|l|}{ Prob } & $0.000 * * *$ & $0.000 * * *$ & $0.000 * * *$ & $0.000 * * *$ & $0.000 * * *$ \\
\hline \multicolumn{7}{|c|}{$\begin{array}{l}* * * \text { significant at } \alpha=1 \% ; * * \text { significant at } \alpha=5 \% ; * \text { significant at } \alpha=10 \% \text {. Whereas: Perf }=\text { Managerial } \\
\text { performance; } \mathrm{BP}=\text { Budgetary participation; } \mathrm{CM}=\mathrm{Cost} \text { management knowledge; } \mathrm{CM} \mathrm{BP}=\text { Interaction } \\
\text { between budgetary participation and cost management knowledge; Sat*BP = Interaction between } \\
\text { budgetary participation and job satisfaction; } \mathrm{CM} \text { Sat = Interaction between cost management } \\
\text { knowledge and job satisfaction; } \mathrm{CM} \text { Sat*BP }=\text { Interaction between cost management knowledge, job } \\
\text { satisfaction, and budgetary participation ( } 3 \text { way interaction); } \mathrm{e}=\text { error. }\end{array}$} \\
\hline
\end{tabular}

All the regression models show significant models statistically, pointed out by the value of Fstat which is significant at probability $<0.0001$. Compared to other models, the highest value of Adjusted $\mathrm{R}^{2}$ is found in the 2-way-interaction and 3-wayinteraction models. However the value of adjusted $\mathrm{R}^{2}$ for the 3-way-interaction is slightly less than that of the 2-way-interaction model. This signifies that the addition of 3 interaction variables does not add to the explanatory power upon the variable on managerial performance.

Column 1 shows that all variables; $\mathrm{BP}, \mathrm{CM}$, and Sat have positive, significant influence on managerial performance. This result stays consistent up to the fifth column which takes into account both the 2-way and the 3 -way interaction variables.

The test results of hypothesis 1 is shown in column 5 , that the 3 interaction variables on $\mathrm{CM}^{*}$ Sat*BP have no impact on managerial performance (Perf). This means that budgetary participation combined with higher cost management knowledge and job satisfaction will result in increased managerial performance. This result is not in line with initial expectations, hence, Hypothesis $\mathrm{H} 1$ is not supported by the data. 
The interaction variableCM*BP throughout columns 2, 4 and 5 consistently produces positive, significant influence on managerial performance. Referring to the regression in column 5 , the test results of hypothesis 2 show that higher cost management knowledge will strengthen the positive influence of budgetary participation on managerial performance, having considered other dimensions which may affect the managerial performance. Thus, hypothesis 2 is supported by the data. This result is in agreement with the earlier research done by Agbejule and Saarikoski (2006),

The interaction variable Sat*BP throughout columns 3,4 and 5 consistently produces positive influence on managerial performance. Referringg to the regression results from column 5 , the test results of hypothesis 3 show that higher job satisfaction will strengthen the positive influence of budgetary participation on managerial performance, having considered other dimensions which may affect the managerial performance. Thus, hypothesis 3 is supported by the data. This result is also consistent with the earlier research done by Setiawaty (2002) which utilized motivation for measuring the "willingness" dimension.

The adjusted value of $\mathrm{R}^{2}$ which does not increase as 3 interaction variables are added shows consistent results with the interaction variable on $\mathrm{CM}^{*}$ Sat*BP which has been insignificant in the 3 -way-interaction model testing. The existence of the interaction variable $\mathrm{CM}^{*}$ Sat*BP does not add explanatory power unto explaining the variations of managerial performance

\section{Sensitivity Test}

Sensitivity test is done by shifting the moderating variables on cost management knowledge (CM) and job satisfaction (Sat) into dummy variables. The use dichotomus variables as moderating variables is suggested by Harman and Moers (1999) in Jermias and Setiawan (2008). Although the use of dichotomus variables reduces explanatory power, it would give meaning to analyses which use more than 2 interaction variables, by observing the differences of influences among dependent variables of various categories.

Variable $\mathrm{CM}$ will equal 1 if the score is above the median, which signifies high level of cost management knowledge, and will equal 0 if the score is below the median, which signifies low level of cost management knowledge. Variable Sat will equal 1 for scores above the median (signifying high level of job satisfaction) and will equal 0 for scores below the median (signifying low level of job satisfaction).

Generally, regression results show consistency and are in line with the main testing, as stated in Table 6 (after being adjusted to the 1-way method using e-views), that interaction variable $\mathrm{CM}^{*} \mathrm{BP} *$ Sat has no significant impact on managerial performance. The interaction between 2 variables which significantly affect managerial performance only occurs in variable DSat*B, while DCM*BP is not significant. By using this categorical variable, although the model is significant statistically, the explanatory power declines considerably compared to the first test.

\section{MANAGERIAL IMPLICATIONS}

Based on the results discussed above, this study found that the 3-way interaction has no effect on managerial performance. We can see that there is an interesting finding from the regression results of the 2-way (column 4) and 3-way (column 5) methods which show that the interaction variable on $\mathrm{CM}^{*}$ Sat has negative, significant influence on managerial performance. This means that higher cost management knowledge and higher job satisfaction will result in lower level of managerial performance.

The interaction variable between cost management knowledge and job satisfaction (CM*Sat in columns 4 and 5), which has negative impact on managerial performance shows that high level of cost management knowledge 
Table 6. Sensitivity test using dummy variables

\begin{tabular}{|c|c|c|c|c|}
\hline Variable & $\begin{array}{c}\text { Expected } \\
\text { Coefficient }\end{array}$ & $\begin{array}{c}\text { Model } \\
\text { (1 way) }\end{array}$ & $\begin{array}{c}\text { Model } \\
\text { (2 way) }\end{array}$ & $\begin{array}{c}\text { Model } \\
\text { (3 way) }\end{array}$ \\
\hline \multicolumn{5}{|c|}{ Dependent Variable: Perf } \\
\hline $\mathrm{C}$ & & $\begin{array}{r}3.414 \\
(0.000) \\
\end{array}$ & $\begin{array}{r}4.434 \\
(0.000) \\
\end{array}$ & $\begin{array}{r}4.467 \\
(0.000) \\
\end{array}$ \\
\hline $\mathrm{BP}$ & + & $\begin{array}{r}0.250 \\
(0.000)^{* * * *} \\
\end{array}$ & $\begin{array}{r}0.095 \\
(0.311) \\
\end{array}$ & $\begin{array}{r}0.137 \\
(0.089) *\end{array}$ \\
\hline DCM & + & $\begin{array}{r}0.338 \\
(0.023)^{* *} \\
\end{array}$ & $\begin{array}{r}0.521 \\
(0.011)^{* *} \\
\end{array}$ & $\begin{array}{r}0.561 \\
(0.002)^{* * * *}\end{array}$ \\
\hline Dsat & + & $\begin{array}{r}0.535 \\
(0.000)^{* * * *} \\
\end{array}$ & $\begin{array}{r}0.647 \\
(0.004)^{* * *} \\
\end{array}$ & $\begin{array}{r}0.606 \\
(0.003) * * * \\
\end{array}$ \\
\hline $\mathrm{DCM} * \mathrm{BP}$ & H3: + & & $\begin{array}{r}0.017 \\
(0.909) \\
\end{array}$ & $\begin{array}{r}-0.126 \\
(0.247) \\
\end{array}$ \\
\hline DSat*BP & $\mathrm{H} 2:+$ & & $\begin{array}{r}0.267 \\
(0.022)^{* *}\end{array}$ & $\begin{array}{r}0.194 \\
(0.058) *\end{array}$ \\
\hline DCM*Dsat & $?$ & & $\begin{array}{r}-0.245 \\
(0.449) \\
\end{array}$ & $\begin{array}{r}-0.326 \\
(0.175) \\
\end{array}$ \\
\hline DCM*DSat*BP & $\mathrm{H} 1:+$ & & & $\begin{array}{r}0.255 \\
(0.189) \\
\end{array}$ \\
\hline $\operatorname{Adj} R^{2}$ & & 0.300 & 0.311 & 0.310 \\
\hline F-stat & & 17.452 & 9.674 & 8.411 \\
\hline Prob & & $0.000 * * *$ & $0.000 * * *$ & $0.000 * * *$ \\
\hline
\end{tabular}

(Capacity dimension) and high level of job satisfaction (willingness dimension) without being accompanied with budgetary participation (opportunity dimension), will result in lower level of managerial performance. It can be inferred that, a middle-level manager who has high capacity and motivation in his/her job, if not given the opportunity to participate in the planning and control activities at the workplace, will have lower performance. Considering the fact that organizational performance is constructed out of the performance of the individuals working in the company, this shows the importance of the participation of middle-level managers in optimizing their capacity and motivation in order to enhance each individual's performance. If managerial performance increases, organizational performance is expected to increase likewise.
The explanation above can be used to explain why the 3 interaction variables of cost management knowledge, job satisfaction, and budgetary participation have no significant impact on managerial performance. Referring to the theories used by Blumberg and Pringle (1982) regarding the factors which affect performance, that performance is influenced by three dimensions of opportunity, capacity, and willingness. Based on the regression results, we find two important findings that the combination of high capacity and motivation without being accompanied by the opportunity for budgetary participation (variable $\mathrm{CM}^{*}$ Sat) will negatively influence managerial performance, while the combination of budgetary participation, cost management knowledge and job satisfaction $\left(\mathrm{CM}^{*} \mathrm{Sat}{ }^{*} \mathrm{BP}\right)$ have no significant influence upon managerial performance. This 
finding shows that the opportunity to participate in budgeting alone is not enough to boost the performance of a manager who has high level of cost management knowledge ("capacity" dimension) and high level of job satisfaction ("willingness" dimension). Managers with high capacity and job satisfaction should probably be given the chance to participate in other planning and controlling activities within the company, such as the the designation of performance indicators and budget control. This affirms the importance of giving the opportunity to participate from the top management to the middle, in order for the middle-management's performance to increase. Hence, this research implies how important it is for middle-level managers who have good capacity and motivation to be given the opportunity to participate more in the company's planning and controlling activities.

\section{CONCLUSION}

This research aims to continue an early research about the influence of participative budgeting on managerial performance. This research strives to explore variables in relation to individual factors, utilizing the theoretical framework from Blumberg and Pringle (1982) that individual performance is affected by three interactive dimensions which are the opportunity dimension (participative budgeting), capacitydimension (cost management knowledge), and willingness dimension (job satisfaction). The previous research only focused on two dimensions (the interaction between 2 variables). This research fills the research gap in Agbejule and Saarikoski (2006) about the infuence of cost management knowledge on the relationship between participative budgeting and managerial performance, by adding the willingness dimension, which is job satisfaction according to the theoretical framework given by Blumberg and Pringle (1982).

Research outcomes have shown that the interaction between three variables which represent the dimensional interaction in the theory of Blumberg and Pringle (1982) has no significant influence on managerial performance. The research outcome confirms the previous research which only used 2 dimensions, in which cost management knowledge enhances the positive impact of budgetary participation on performance, and job satisfaction enhances the positive impact of budgetary participation on managerial performance. The next analysis shows that high level of job satisfaction and cost management knowledge with no budgetary participation would reduce managerial performance. This finding is consistent with the hypothesis test results which argue that budgetary participation alone would not be sufficient in order to increase the performance of managers who have high cost management knowledge and job satisfaction.

This research has limitations in several aspects, which are (1) the respondents are limited to managers working in Jakarta and Depok area, making them hard to generalize; (2) performance evaluation uses a list of "self assessment" questions which may provoke bias; (3) The "willingness" and "capacity" dimensions are only represented by one form of measurement. To confirm this study result, further research can use other measurements to represent the willingness dimension, such as motivation and the knowledge and experience about budget planning and evaluation for the capacity dimension. 


\section{REFERENCES}

A. Agbejule, L. Saarikoski. (2006). "The Effect of Cost Management Knowledge on The Relationship Between Budgetary Participation and Managerial Performance." The British Accounting Review 38 (2006) 427-440.

Blumberg, M., Pringle, C., (1982). "The Missing Opportunity in Organizational Research: Some Implications for a Theory of Work Performance." Academy of Management Review, 1982. Vol. 7, No. 4, 560 - 569.

Brownell, P., \& Merchant, K. (1990).” The Budgetary and Performance Influences Of Product Standardization and Manufacturing Process Automation." Journal of Accounting Research,28, 388-397.

Brownell, P., \& Dunk, A. (1991)." Task Uncertainty and Its Interaction with Budgetary Participation and Budget Emphasis: Some Methodological Issues and Empirical Investigation." Accounting, Organizations and Society, 16,693-703.

Chenhal, R., \& Brownell, P. (1988)." The Effect of Participative Budgeting on Job Satisfaction and Performance: Role Ambiguity as an Intervening Variable." Accounting, Organizations and Society, I. 225-234.

Covaleski, M., Evans, Luft, Shields. (2003). "Budgeting Research: Three Theoretical Perspectives and Criteria for Selective Integration." Journal Of Management Accounting Research. Volume Fifteen. pp. 3-49

Dunk, A. (1993)." The Effect of Budget Emphasis and Information Asymmetry on The Relation Between Budgetary Participation and Slack." The Accounting Review, 68, 400-410.

Govindarajan, V., (1986). "Impact of Participation in The Budgetary Process on Managerial Attitudes and Performance: Universalistic And Contingency Perspectives." Decision Sciences 17, 496-516.

J. Jermias, T. Setiawan. (2008)." The Moderating Effects of Hierarchy and Control Systems on The Relationship between Budgetary Participation and Performance." The International Journal of Accounting, 43 (2008) 268-292

Kenis, I. (1979). "Effects of Budgetary Goal Characteristics on Managerial Attitudes and Performance.” The Accounting Review, $54,707-721$

Kren, L. (1990)." Performance in a Budget-Based Control System: An Extended Expectancy Theory Model Approach." Journal of Management Accounting Research, 2,100-1 12.

Lopez, M., Stammerjohan, W., Lee, Kyoo Sang. (2009). "Budget Participation and Job Performance of South Korean Managers Mediated by Job Satisfaction and Job Relevant Information," Management Research News, Vol. 32 No. 3. pp. 220-238

Mahoney, T., Jerdee, T., Carroll, S., (1965). “The Jobs of Management.” Industrial Relations 4, 97-110.

Meiliana. (2003). "Ketidakpastian Lingkungan dan Informasi Job relevant sebagai Variabel yang Memoderasi Pengaruh Karakteristik Sistem Penganggaran terhadap Kinerja Manajerial," Tesis. Magister Akuntansi, Fakultas Ekonomi Universitas Indonesia. Tidak dipublikasikan.

Merchant, K. (1984). Influences on Departmental Budgeting: an Empirical Examination of a Contingency Model. Accounting, Organizations and Society, 9, 291-310.

Mia, L. (1988). “ Managerial Attitude, Motivation and The Effectiveness of Budget Participation." Accounting, Organizations and Society, 13, 465-476.

Patterson, M., West, M. A., Lawthom, R., Nickell, S. (1997). "Impact of People Management Practises on Business Performance." Issues in People Management. Institute of Work Psychology, University of Sheffield. Institute of Personnel and Development, London, UK.

Setiawaty, Anita Endang. (2002). "Pengaruh Motivasi terhadap Keefektifan Penganggaran Partisipatif dalam Peningkatan Kinerja Manajerial,” Tesis. Magister Akuntansi, Fakultas Ekonomi Universitas Indonesia. Tidak dipublikasikan.

Setyadi, Heru. (2002). "Pengaruh Locus of Control terhadap Keefektifan Penganggaran Partisipatif dalam Peningkatan Kinerja Manajerial.” Tesis. Magister Akuntansi, Fakultas Ekonomi Universitas Indonesia. Tidak dipublikasikan.

Shields, M. D., and S. M. Young. (1993). "Antecedents and Consequences of Participative Budgeting: Evidence on The Effects of Asymmetrical Information." Journal of Management Accounting Research 5: 265-280.

Shields, M., Young, M., (1994)." Managing Innovation Costs: a Study of Cost Conscious Behavior by R\&D Professionals." Journal of Management Accounting Research 6, 175-196.

Shields, M., Shields, D. (1998). "Antecedents of Participative Budgeting." Accounting Organizations and Society 23, 49-76.

Weiss, D.J., Davis, R.V., England, G.W. and Lofquist, L.H. (1967). "Manual for The Minnesota Satisfaction Questionnaire," Minnesota Studies in Vocational Rehabilitation XXII, October, Bulletin 45. 